\section{Electrical Development in Northern Ireland}

AN experiment on the co-ordination of electricity distribution is now in its fourth year in Northern Ireland. With the exception of the areas covered by the county borough undertakings of Belfast and Londonderry and by the Antrim Electricity Supply Co., practically the whole of Northern Ireland is included. By an Act passed by the Parliament of Northern Ireland in 1931, a Board was set up, the duties of which were to promote, co-ordinate and improve the supply distribution of electricity generally throughout the country. The Act specially laid down that the Board should not be a profit-earning body and that the members should not be financially interested in any company engaged in electrical work. In a paper read to the Institution of Electrical Engineers on January 23, Mr. C. R. Westlake showed that the policy of co-ordination is proving successful, and that the public now has a service of electricity supply not possible under the previous types of control. The main source of supply in Northern Ireland is the harbour power station of the Belfast Corporation, and the area round it is populous. The area taken for primary development covers 1,200 square miles and has a population of about 300,000 . The Board can purchase its supplies from any authorised undertakers, and it has adequate equipment to provide for rapid and continuous growth. The problem is to supply energy at rates low enough to secure growth and at the same time to secure sufficient revenue. Notwithstanding the competition of gas companies, more than 50 per cent of the potential consumers are already connected, and where there is no competition, 'saturation' is attained almost immediately. Whole areas hitherto without supply have now amenities usually associated with city life without loss of their rural surroundings. This successful experiment shows the trend of public policy towards the co-ordination of all public utility undertakings.

\section{Japanese Patents and Inventions}

ON December 23, 1934, the Japan Times and Mail published a special "Invention Number" in connexion with the commemoration of the jubilee of the Japanese patent law. The number contains much interesting matter regarding the birth and growth of the Patent Bureau, the increase in the number of patents applied for and sanctioned, and the place of Japan as a great industrial nation. The early history of the Patent Bureau, which in 1933 had a staff of 600 , was dealt with in a broadcast address by the Minister of Finance, Mr. K. Takahashi, who was the first chief of the Bureau. The first law enacted by the Government for the protection of inventions, he said, was the so-called expedient monopoly regulations promulgated on April 7, 1871. This, however, was never enforced and in the following year was abolished. A special committee was next appointed to examine the British and American patent laws, and from its work sprang the first Trade-Mark Act in Japan, promulgated on October 1, 1884, followed by the Patent Act of April 18, 1885. This Act came into force on July 1, and No. I patent was issued that day to a Tokyo citizen, Zuisho Hotta, for a coating material for ships and iron bridges. For the first twenty years, patents and inventions failed to attract much public attention, and whatever progress was made in industry was due more to successful imitation of Western practices than to original discovery or invention. From the time of the Russo-Japanese War, however, largely through the action of the body now known as the Imperial Invention Association, invention has been encouraged by the Government, and to-day Japan now claims to rank only behind the United States and Germany in the number of patents granted. In several of the contributions to the "Invention Number", recognition is given to the debt Japan owes to foreign countries, but there is also a just sense of pride in the status to which she has attained through her own initiative.

\section{Gas Warfare by Air}

THE large number of publications in Germany dealing with all aspects of gas warfare which have appeared during the last two years is well known to all in touch with the German technical press, and increasing attention has been devoted to this matter in Great Britain also in recent months. The pamphlet entitled "The Menace of Aerial Gas Bombardment" by Lieut.-Col. N. G. Thwaites, which has now been issued by the New Commonwealth, is a welcome statement of the facts in a matter in which conflicting expert opinions have confused the public mind. Reviewing the situation in the different countries of Europe, Col. Thwaites points out that the danger of gas attack from the air is taken very seriously by Germany, France and Italy, while Russia is openly preparing for chemical warfare. In Germany no opportunity is lost of educating the public in anti-gas precautions, and a widely circulated "Handbook of Air Defence" was issued in May 1934. Equipment of the public with gas masks has not yet proceeded very far. In France the public has been made aware of the danger of aerial gas attack, and gas masks are now being sold in large quantities after testing by the authorities. In Italy, anti-gas precautions are dominant among the measures taken for defence against air attack, and the supply and distribution of gas masks has been carried further than in other countries; in Poland a League for Aerial Defence against Gas receives strong support from the Government.

Col. Thwattes proceeds to discuss briefly the measures being taken in Great Britain, as well as the probability and horrors of gas warfare. In his view, the defence measures so far taken are futile, and no merely technical remedy is likely to suffice for long. He considers that the only effective remedy is the abolition by mutual agreement of all national military air forces and the establishment of an international air force for policing purposes. The alternative policy of isolation is no longer possible and the present condition of air strategy puts a premium on the aggressor. The technical difficulties in the

(Continused on p. 227.) 
organisation of an International Air Police are insignificant compared with the difficulty of finding any practical defence scheme which has the remotest chance of becoming effective.

\section{Civil Aviation Wireless Plans}

The plans which have been approved for the establishment of new civil aviation wireless stations in Great Britain will provide for the establishment of a chain of wireless stations throughout the country, so as to afford full facilities for direction-finding, for communication with aircraft, and between airports. Three new stations came into operation last year, at Hull, Portsmouth and Newtownards (Belfast). A further six are under construction and will be placed at suitable sites during 1935 . These sites are being chosen with the object of providing a direction-finding network covering the new internal routes, as well as to serve the needs of individual aerodromes. The equipment will be mounted on vehicles capable of being easily moved from place to place. A limited number of permanent stations of higher power are also to be erected. The first of these will be established at Heston Airport to relieve the growing congestion at Croydon. It is also the intention of the local authorities to build a station in the Channel Isles. Three new permanent directionfinding stations, in addition to those already existing at the same points, are being brought into operation at an early date on the Continental airway, at Pulham, Lympne and Croydon. The radio-beacon at Croydon is now being modified to operate on the aural principle, thus making it available for any aircraft fitted with an ordinary receiver. On the completion of this reorganisation there will be available for the assistance of aircraft flying on the Continental routes seven direction finders, seven transmitters and one radio-beacon.

\section{A New Depth-Sounding Recorder}

THere are several types of marine devices for finding the depth of the sea by means of 'echosounding'. One or two of these not only give isolated indications of the depth of the sea, but also provide a more or less continuous record of the sea bed. The British Admiralty uses a low-frequency type of oscillation which is reflected from the bottom of the sea, the time of going and returning being marked on an electro-chemical recorder. A high-frequency system using the vibrations of a quartz piezo-electric oscillator, devised by Langevin and Chilowsky, has been developed commercially in Great Britain by the Marconi Sounding Device Co, An entirely new type of high-frequency echo depth recorder which possesses important advantages was described to the Institution of Electrical Engineers on January 2 by A. B. Wood, F. B. Smith and J. A. McGeachy. This device can give a continuous record of the depth of water beneath a survey motor-boat of about $2 \mathrm{ft}$. draught travelling at full speed. According to the specification, it had to measure a depth ranging up to 200 feet with a maximum inaccuracy of about one foot. The method employed gives a practical application of the phenomenon of magneto-striction. Two oscillators of this type-a transmitter.and a receiver-are mounted in water-filled tanks and fitted in a chosen position in the motor-boat. The transmitter is excited into resonant vibration at regular intervals of time depending on the range of depth to be recorded. A short train of high-frequency sound waves is directed vertically downwards to the sea-bed and reflected back to the receiver. The induced currents are amplified, rectified and passed through a recorder. During the time the sound impulse is travelling from the transmitter to the receiver via the sea bed, the recording point has travelled a corresponding distance on the paper. The time for the going and return journey is thus found. The method has been proved satisfactory for depths exceeding 400 fathoms.

\section{Vital Statistics for 1933}

LAST week (p. 181) we printed a note referring to the provisional figures of the vital statistics for 1934 . The Registrar-General's Statistical Review for 1933, Tables (Part II, Givil) is now available (London: H.M. Stationery Office. $2 s, 0 d$.). It includes a table showing the populations of England and Wales, Scotland and Ireland as enumerated at each Census from 1821 until 1931, and as estimated for each year 1894-1933 inclusive. The population of England and Wales is now estimated as 40,350,000 at the middle of 1933, the 1931 Census figure being $39,952,377$. The births registered during 1933 numbered 580,413 a decrease of 33,559 on the previous year's figure. The consequent birth rate of $14 \cdot 4$ per 1,000 population is the lowest recorded for England and Wales, being 0.9 below that for 1932 the previous lowest, and 1.4 below that for 1931. The only countries showing a lower rate in 1933 were Sweden $(13 \cdot 7)$ and Austria $(14 \cdot 3)$. The proportion of the sexes in the births registered during the year was 1,046 males to 1,000 females.

\section{Association of American Geographers}

THE thirty-first annual meeting of the Association of American Geographers, with Dr. Wallace $\mathrm{W}$. Atwood presiding, was held at the University of Pennsylvania, Philadelphia, on December 27-29. Forty-nine papers were presented, including six in the field of geomorphology, five in climatology, and two in cartography. The remaining papers ranged the whole field of geography, and included discussions of particular problems or areas. A half-day session was devoted to a conference on regional geography. As retiring president, Dr. Atwood addressed the Association on "The Increasing Significance of Geographic Conditions in the Growth of Nation States". For the fortheoming year the following officers were elected: President, Prof. Charles C. Colby, University of Chicago; Vice-President, Col. C. H. Birdseye, U.S. Geological Survey; Treasurer, Prof. John E. Orchard, Columbia University ; Councillor, Prof. Kirk Bryan, Harvard University; Secretary, Prof. Frank E. Williams, University of Pennsylvania. 